\title{
Spontaneous viral clearance of hepatitis C virus (HCV) infection among people who inject drugs (PWID) and HIV-positive men who have sex with men (HIV+ MSM): a systematic review and meta-analysis
}

Daniel J. Smith ${ }^{1 *}$, Ashly E. Jordan ${ }^{1,2}$, Mayu Frank ${ }^{1}$ and Holly Hagan ${ }^{1,2}$

\begin{abstract}
Background: Hepatitis C virus (HCV) infection causes significant morbidity and mortality among people who inject drugs (PWID) and HIV+ men who have sex with men (MSM). Characterizing spontaneous viral clearance of HCV infection among PWID and HIV+ MSM is important for assessing the burden of disease and treatment strategies in these populations.

Methods: Electronic and other searches of medical literature were conducted. Reports were eligible if they presented original data from upper-middle- and high-income countries on laboratory-confirmed HCV infection and spontaneous viral clearance among PWID or HIV+ MSM. Pooled estimates of spontaneous viral clearance were generated using fixed-effect and random-effects models. Meta-regression examined potential predictors related to individual characteristics and research methodology.
\end{abstract}

Results: The meta-analysis estimated that spontaneous viral clearance occurs in $24.4 \%$ of PWID and $15.4 \%$ of HIV+ MSM. In univariate meta-regression among PWID, male sex and age were significantly associated with spontaneous viral clearance, and in multivariate analysis, male sex and HIV positivity were predictors of spontaneous viral clearance; among HIV+ MSM no variables were found to affect spontaneous viral clearance.

Conclusion: The variability in estimates of spontaneous viral clearance between HIV+ MSM and PWID suggests the impact of HIV co-infection and HCV re-infection. Due to limited data on additional factors that may affect the natural history of HCV, more research is needed to further understand spontaneous viral clearance in these risk groups.

Protocol registration: The protocols for the PWID and HIV+ MSM research were registered with PROSPERO (CRD42014008805; CRD42013006462).

Keywords: Hepatitis C virus, MSM, PWID, Systematic review, Meta-analysis, Spontaneous HCV clearance Abbreviations: $\mathrm{Cl}$, Confidence interval; HCV, Hepatitis C virus; HIV, Human immunodeficiency virus; HIV+ MSM, Human immunodeficiency virus-positive men who have sex with men; PWID, People who inject drugs; SE, Standard error

\footnotetext{
* Correspondence: dan.smith@nyu.edu

${ }^{1}$ Rory Meyers College of Nursing, New York University, New York, NY 10010,

USA

Full list of author information is available at the end of the article
} 


\section{Background}

Approximately $3 \%$ of the world's population is infected with hepatitis $\mathrm{C}$ virus ( $\mathrm{HCV}$ ), a blood borne infection that is almost entirely attributable to parenteral exposure via non-sterile injection equipment used in medical settings or to inject drugs [1]. After clinical or subclinical HCV infection up to $25 \%$ of people will spontaneously clear the virus [2]. There is significant excess mortality attributable to liver-related injury in those with chronic $\mathrm{HCV}$ infection compared to the general population, and among those with chronic $\mathrm{HCV}$ infection, progression of the disease varies widely $[3,4]$.

Among people who inject drugs (PWID), high HCV incidence rates of 10-40 infections/100 person-years (PYs) contribute to a persistent and high population prevalence of 43-80 \% [5-7]; as such, HCV is endemic among PWID [8].

Co-infection with HIV and $\mathrm{HCV}$ is common due to shared routes of disease transmission. HIV/HCV co-infection contributes to substantial, yet preventable, morbidity and mortality; specifically, liver disease progression is accelerated in HIV co-infected individuals $[9,10]$. Co-infection with HIV and HCV is of considerable relevance to PWID as the majority of HIV-positive PWID also are infected with HCV (50-70 \%) [11].

Within the HIV-positive population, sexual transmission of $\mathrm{HCV}$ also is a concern $[12,13]$. In a recent metaanalysis, the incidence rate of $\mathrm{HCV}$ infection among HIVpositive men who have sex with men (HIV+ MSM) who are non-PWID was found to be $0.53 / 100$ PYs [14]. While low, incidence of $\mathrm{HCV}$ in this population is expected to increase [14]. In a related meta-analysis, HCV prevalence was estimated to be $12 \%$ among HIV+ MSM [15].

Characterizing spontaneous viral clearance of $\mathrm{HCV}$ infection among PWID and HIV+ MSM is important for assessing the burden of disease and the need for treatment in these populations. In this systematic review and meta-analysis, we synthesized the literature on the prevalence of spontaneous viral clearance within PWID and HIV+ MSM populations. This systematic review and meta-analysis and related simulations are conducted as part of the HCV Synthesis Project, which is funded to develop guidance and recommendations for $\mathrm{HCV}$ control strategies in the US [14-19].

\section{Methods}

\section{Search strategy}

Both electronic and manual searches for published literature were conducted. The databases of CINAHL, OVID, ProQuest, PubMed, and Web of Science were searched using the following terms: "HCV," "hepatitis C," "natural history," "disease progression," "clearance," and "resolution." For the HIV+ MSM group, the search string included variations of the terms "HIV," "human immunodeficiency virus," "AIDS," "acquired immunodeficiency syndrome," "men who have sex with men," "homosexual," and "gay." Reports examining PWID were sought through the incorporation of the keywords "PWID," "injection drug use," and "intravenous drug use". (See Additional file 1 for complete search strategies.)

Searches were refined using filters for publication date, peer-reviewed journal, and human studies. Additional literature was retrieved through manual searches of the reference lists of eligible reports, review articles, and methodological papers. The conduct and reporting of this project was guided by the Preferred Reporting Items for Systematic Reviews and Meta-Analyses (PRISMA) [20]. The protocols for the HIV+ MSM and PWID research were registered with PROSPERO (CRD42013006462; CRD42014008805) and subsequently published $[16,18]$.

\section{Inclusion and exclusion criteria PWID}

Reports that met the following criteria were eligible for inclusion in the review: (i) included participants with laboratory confirmed $\mathrm{HCV}$ infection and who reported current or previous injection drug use (hereafter referred to as PWID); (ii) presented original data on spontaneous viral clearance in a study sample comprised of at least 90 \% PWID; (iii) published between January 1, 1990, and April 1, 2014; and, (iv) provided data on participants from upper-middle- or high-income countries. The condition in (iv) was based on the prevalence of the hepatitis B virus (HBV) carrier state, which is associated with lower rates of $\mathrm{HCV}$ clearance [21]. Across uppermiddle- and high-income countries, the HBV carrier rate is less than $2 \%$ whereas areas of high HBV endemicity are comprised of predominately lower-income countries such as Southeast Asia, Sub-Saharan Africa, and the Amazon Basin; HBV carrier rates in these regions are upwards of $8 \%$ [22] and may be higher among those at risk of HIV or HCV. Reports were excluded if HIV or HBV co-infection was present in greater than $50 \%$ of the PWID study sample, or if participants were receiving or previously had received HCV treatment. (Seven reports included HIV-positive PWID (range 1.8-57.1\%).)

\section{$H I V+M S M$}

The following eligibility criteria were applied: (i) included male participants co-infected with HIV infection and with laboratory confirmed acute $\mathrm{HCV}$ infection and who reported having sex with other men (hereafter referred to as MSM); (ii) presented original data on spontaneous viral clearance in a study sample comprised of at least $90 \% \mathrm{HIV}+\mathrm{MSM}$; (iii) published between January 1, 1996, and April 1, 2014; and, (iv) provided data on participants from upper-middle- or high-income countries. We established the condition in (iii) to 
account for the introduction in 1996 of highly active anti-retroviral therapy (HAART), which represented a significant change in the standard of care, and thus the natural history, of HIV infection. Accordingly, HAART may affect the disease progression of individuals coinfected with HIV and acute HCV. The restriction that participants had acute $\mathrm{HCV}$ allowed for the observation of the effect of HIV infection on the course of newly acquired $\mathrm{HCV}$ infection. The condition in (iv) follows from the assumption that health outcomes are influenced by the disparity between income-based country groups in the accessibility and completeness of coverage of HAART to HIV-positive individuals; a wide gap exists between treatment and need in low-income countries [23].

\section{$\mathrm{HCV}$ infection measure}

The primary exposure of interest was acute or chronic $\mathrm{HCV}$ infection. The preferred criteria for defining acute $\mathrm{HCV}$ infection employed in our review was that endorsed by the European AIDS Treatment Network (NEAT) for which the criteria were seroconversion or a positive HCV RNA test following a documented negative $\mathrm{HCV}$ RNA or negative $\mathrm{HCV}$ antibody test in the previous 12 months [24]. Our alternative criterion for defining acute $\mathrm{HCV}$ infection required a statement in the report that all patients were acutely infected. Chronic infection was defined by HCV RNA positivity.

The importance of defining whether or not $\mathrm{HCV}$ was acute was less critical to those without HIV infection; however, in those with HIV the demonstration of acute infection (either by the preferred or alternative criteria) was relevant in asking whether HIV co-infection impacts spontaneous viral clearance. Among the reports presenting data on spontaneous viral clearance among HIV+ MSM, all participants acquired HIV infection prior to $\mathrm{HCV}$ infection; among PWID the sequence of disease acquisition was less clear.

\section{Outcome measures}

The outcome of interest was the prevalence of spontaneous viral clearance. Spontaneous viral clearance was measured in cross-sectional studies as at least one negative or undetectable RNA test result and in longitudinal studies as consecutive negative or undetectable RNA test results. In some reports the definition of spontaneous viral clearance was not presented, but data were available on the outcome of interest.

\section{Screening and data collection}

Two research assistants (RAs) screened abstracts and extracted data. The project director and the principal investigator reviewed all eligible reports and made final decisions on inclusion in the review and meta-analysis.
We collected from the included reports data on the following domains: citation information; study cohort, period, and location; study design and methods; incidence and prevalence of spontaneous viral clearance; disease duration; and participant characteristics, particularly factors understood to be associated with clearance (e.g., age, sex, and HIV co-infection). For any report with missing or inconsistent data, we contacted the corresponding author for additional information or clarification. Among the set of reports examining PWID, six authors were contacted, and four fulfilled our data requests $(67 \%)$. Three of six authors provided additional data on HIV+ MSM (50 \%).

\section{Report quality}

Quality appraisal of each report included in this systematic review was based on an adapted version of the Quality In Prognosis Studies (QUIPS) tool, which was developed to assess potential biases in studies of prognostic factors $[25,26]$. (The complete adapted instrument is available by request.) Each report was assigned an overall rating of high, moderate, or low, which indicated the extent to which the study design and analysis controlled for the influence of selection bias, misclassification, and confounding.

\section{Data analysis}

Report-level prevalence of spontaneous viral clearance was estimated using the binomial distribution. Pooled estimates of spontaneous viral clearance were generated using both fixed-effect and random-effects models. The Cochran's $Q$ and $I^{2}$ [27] measures provided assessments of heterogeneity, and random-effects meta-regression was performed to examine variability among the reportlevel estimates of spontaneous viral clearance.

We examined the possibility of assessing the role of previous infection with HIV on spontaneous viral clearance among PWID; however, because most studies did not specify which of HIV or HCV was acquired first, we were not able to directly examine this. Those PWID who were HIV positive and had unequivocal evidence of spontaneous viral clearance most likely represented an individual in whom the sequence of events was HCV infection, followed by spontaneous viral clearance, and subsequently HIV infection. All statistical analysis was conducted using Stata 13.1 [28].

\section{Results \\ Meta-analysis PWID}

A total of 7,488 reports were retrieved from the literature searches, and 28 were included in the final review (see Fig. 1). The reports are described in Table 1. The majority of reports described studies located in Europe 


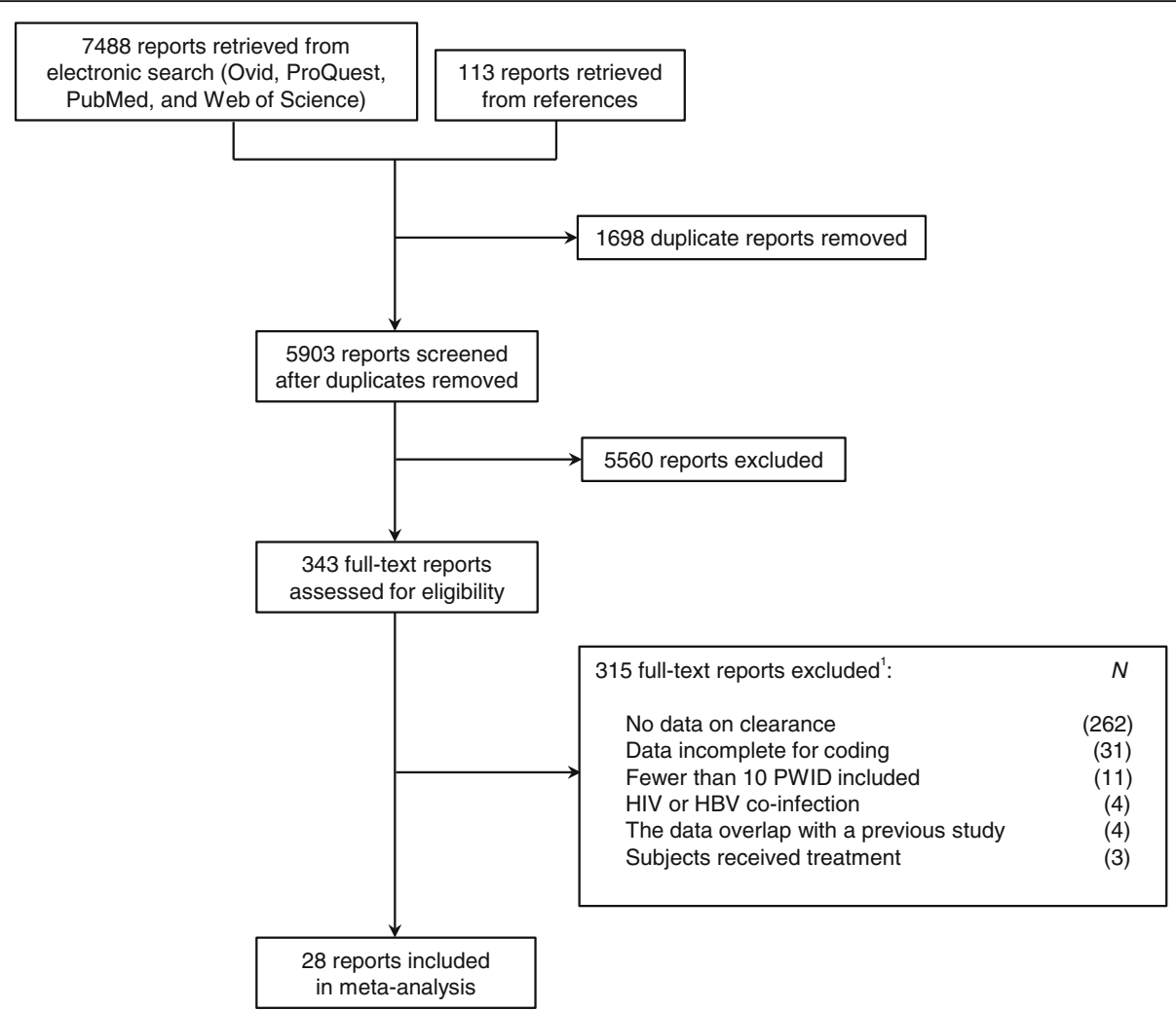

Fig. 1 Flow diagram of the literature search and eligibility assessment for PWID. ${ }^{1}$ Reasons for exclusion are not mutually exclusive. A report may have been ineligible due to multiple reasons. Here, only one reason for exclusion is provided

(12; $43 \%)$; the remaining samples were from the United States (7; $25 \%)$, Australia (5; $18 \%)$, China (2; $7 \%)$, Canada $(1 ; 4 \%)$, and Iran $(1 ; 4 \%)$. Data on participant attributes were presented in greater than $50 \%$ of all reports. Sixteen reports (57\%) presented age at enrollment, eighteen $(64 \%)$ provided the sex distribution, and sixteen $(57 \%)$ stated the proportion of HIV-positive individuals.

All 28 reports were included in the meta-analysis. Among 5,569 PWID, whose mean age at enrollment was 29.6 years (median 27.4; 15 reports), spontaneous viral clearance was observed in 1,236 participants. The random-effects meta-analysis estimate of the prevalence of spontaneous viral clearance was $24.3 \%$ (95\% CI 19.5, 29.1; $\left.Q=638.51, p<0.001 ; I^{2}=95.8 \%\right)$. The estimate from each study is presented in the forest plot in Fig. 2.

Pooled subgroup estimates also were generated to account for HIV status and quality rating. Within the sets of reports for which there were data on the HIV status of PWID, spontaneous viral clearance occurred in $25.7 \%$ (95 \% CI 16.4, 35.0; 13 reports) of HIV-negative participants and in $16.1 \%$ (95 \% CI 12.5, 19.6; 3 reports) of HIV-positive participants. In stratifying the reports by quality rating, as depicted in Table 3 , the prevalence of spontaneous viral clearance was 27.6, 24.1, and $15.4 \%$ among high-, moderate-, and low-quality reports, respectively.

\section{$H I V+M S M$}

Following from Fig. 3, the literature searches yielded 2,417 reports, of which 10 were included in the present analysis; these reports are detailed in Table 2 . Seven of the reports $(70 \%)$ were on studies with cohorts drawn only from Europe. One report (10 \%) examined a sample from the United States, and another report (10 \%) assessed samples from North America, Australia, and Europe. The study location was not described in one report. Few participant characteristics were summarized consistently across the reports. Age at enrollment was presented in five reports (50\%), proportion on HAART in three reports $(30 \%)$, and duration of HIV infection in one report (10\%).

Only 9 of the 10 reports were included in the metaanalysis. One report provided a count of zero spontaneous clearance events in the sample. We chose the conservative approach to handling the zero-count issue, which was to exclude the report from the pooled analysis.

In aggregate, there were $588 \mathrm{HIV}+\mathrm{MSM}$ with a mean age of 40.0 years (median 40.7; 4 reports); 96 
Table 1 Studies investigating spontaneous viral clearance of HCV among PWID

\begin{tabular}{|c|c|c|c|c|c|c|c|c|c|c|c|c|}
\hline \multirow[t]{2}{*}{ First author (pub. yr.) } & \multirow[t]{2}{*}{ Study period } & \multirow[t]{2}{*}{ Location } & \multirow[b]{2}{*}{ Recruitment method } & \multirow[b]{2}{*}{ Recruitment site } & \multirow[b]{2}{*}{$\begin{array}{l}\text { Definition of } \\
\text { HCV clearance }\end{array}$} & \multirow[b]{2}{*}{ Quality rating } & \multicolumn{2}{|l|}{$N$} & \multirow[b]{2}{*}{$\begin{array}{l}\text { Proportion of } \\
\text { clearance events }\end{array}$} & \multirow{2}{*}{\multicolumn{2}{|c|}{$95 \% \mathrm{Cl}$}} & \\
\hline & & & & & & & Participants & Clearers & & & & \\
\hline Aberle (2006) [34] & $2003-2005$ & Austria & Convenience sampling & Clinical setting & $\begin{array}{l}\text { Methods not } \\
\text { reported }\end{array}$ & Low & 11 & 3 & 27.3 & 1.0 & - & 53.6 \\
\hline Aitken (2008) [35] & 2005-2008 & Australia & Convenience sampling & $\begin{array}{l}\text { Community-based } \\
\text { setting }\end{array}$ & 1 RNA- result & Moderate & 135 & 41 & 30.4 & 22.6 & - & 38.1 \\
\hline $\begin{array}{l}\text { Alanko Blome } \\
\text { (2014) [36] }\end{array}$ & 1997-2005 & Sweden & Consecutive sampling & Other setting & 1 RNA- result & High & 150 & 48 & 32.0 & 24.5 & - & 39.5 \\
\hline Boodram (2011) [37] & $2002-2006$ & United States & Convenience sampling & $\begin{array}{l}\text { Community-based } \\
\text { setting }\end{array}$ & $\begin{array}{l}\geq 1 \text { RNA- result } \\
\text { over } 6 \text { months }\end{array}$ & High & 113 & 38 & 33.6 & 24.9 & - & 42.3 \\
\hline Cournot (2004) [38] & 1999-2004 & France & Consecutive sampling & Clinical setting & 1 RNA- result & Moderate & 178 & 27 & 15.2 & 9.9 & - & 20.4 \\
\hline Currie (2008) [39] & 1997-2007 & United States & Convenience sampling & $\begin{array}{l}\text { Clinical and drug } \\
\text { treatment settings }\end{array}$ & $\begin{array}{l}\geq 2 \text { consecutive } \\
\text { RNA- results }\end{array}$ & Moderate & 215 & 29 & 13.5 & 8.9 & - & 18.1 \\
\hline Dolan (2010) [40] & $2005-2007$ & Australia & Convenience sampling & Correctional setting & 1 RNA- result & Moderate & 16 & 6 & 37.5 & 13.8 & - & 61.2 \\
\hline Garten (2008) [41] & 1999-2008 & China & Unspecified sampling & Clinical setting & 1 RNA- result & Low & 347 & 30 & 8.6 & 5.7 & - & 11.6 \\
\hline Gerlach (2003) [42] & 1993-2003 & Germany & Consecutive sampling & Clinical setting & $\begin{array}{l}\geq 1 \text { RNA- result } \\
\text { over } 6 \text { months }\end{array}$ & High & 15 & 5 & 33.3 & 9.5 & - & 57.2 \\
\hline Gjeruldsen (2003) [43] & 1997-1999 & Norway & Consecutive sampling & Clinical setting & 1 RNA- result & Moderate & 50 & 8 & 16.0 & 5.8 & - & 26.2 \\
\hline Grebely (2007) [44] & 1992-2005 & Canada & Convenience sampling & $\begin{array}{l}\text { Community-based } \\
\text { setting }\end{array}$ & $\geq 1$ RNA- result & High & 431 & 91 & 21.1 & 17.3 & - & 25.0 \\
\hline Hallinan (2007) [45] & $2002-2005$ & Australia & Consecutive sampling & $\begin{array}{l}\text { Drug treatment } \\
\text { setting }\end{array}$ & 1 RNA- result & Moderate & 145 & 43 & 29.7 & 22.2 & - & 37.1 \\
\hline Hsieh (2014) [46] & 2008-2010 & China & Unspecified sampling & Correctional setting & $\begin{array}{l}\text { Methods not } \\
\text { reported }\end{array}$ & Low & 513 & 99 & 19.3 & 15.9 & - & 22.7 \\
\hline Jauncey (2004) [47] & 1992-2002 & Australia & Consecutive sampling & Clinical setting & $\begin{array}{l}\geq 2 \text { consecutive } \\
\text { RNA- results }\end{array}$ & High & 57 & 24 & 42.1 & 29.3 & - & 54.9 \\
\hline Keating (2005) [48] & 1997-2001 & Ireland & Consecutive sampling & $\begin{array}{l}\text { Drug treatment } \\
\text { setting }\end{array}$ & $\begin{array}{l}2 \text { consecutive RNA- } \\
\text { results separated by } \\
\text { at least } 12 \text { months }\end{array}$ & High & 496 & 191 & 38.5 & 34.2 & - & 42.8 \\
\hline Kielland (2013) [49] & 1970-2008 & Norway & Consecutive sampling & $\begin{array}{l}\text { Drug treatment } \\
\text { setting }\end{array}$ & 1 RNA- result & Moderate & 523 & 195 & 37.3 & 33.1 & - & 41.4 \\
\hline Lidman (2009) [50] & $2004-2006$ & Sweden & Consecutive sampling & Clinical setting & 1 RNA- result & Moderate & 268 & 61 & 22.8 & 17.7 & - & 27.8 \\
\hline Mattsson (1993) [51] & 1991-1993 & Sweden & Consecutive sampling & $\begin{array}{l}\text { Population-based } \\
\text { setting }\end{array}$ & 1 RNA- result & Moderate & 12 & 4 & 33.3 & 6.7 & - & 60.0 \\
\hline Meyer (2007) [52] & $2002-2007$ & Germany & Consecutive sampling & Correctional setting & $\geq 1$ RNA- result & Moderate & 90 & 23 & 25.6 & 16.5 & - & 34.6 \\
\hline Osburn (2010) [53] & 1997-2007 & United States & Convenience sampling & $\begin{array}{l}\text { Clinical, drug } \\
\text { treatment, and } \\
\text { community-based } \\
\text { settings }\end{array}$ & $\begin{array}{l}\geq 1 \text { RNA- result } \\
\text { over } 2 \text { months }\end{array}$ & Moderate & 113 & 31 & 27.4 & 19.2 & - & 35.7 \\
\hline
\end{tabular}


Table 1 Studies investigating spontaneous viral clearance of HCV among PWID (Continued)

\begin{tabular}{|c|c|c|c|c|c|c|c|c|c|c|c|c|}
\hline $\begin{array}{l}\text { Ostapowicz } \\
\text { (1999) [54] }\end{array}$ & 1990-1999 & Australia & Unspecified sampling & Clinical setting & 1 RNA- result & Moderate & 142 & 2 & 1.4 & -0.5 & - & 3.3 \\
\hline Page (2013) [55] & 2000-2011 & United States & Convenience sampling & Unspecified & $\geq 2$ RNA- results & High & 109 & 26 & 23.9 & 15.9 & - & 31.9 \\
\hline Poustchi (2011) [56] & 2004-2008 & Iran & Other systematic & $\begin{array}{l}\text { Clinical and } \\
\text { research setting }\end{array}$ & $\begin{array}{l}1 \text { RNA- result after } \\
6 \text { months }\end{array}$ & Moderate & 28 & 4 & 14.3 & 1.3 & - & 27.2 \\
\hline $\begin{array}{l}\text { Santantonio } \\
\text { (2006) [57] }\end{array}$ & 1999-2004 & Italy & Unspecified sampling & Clinical setting & $\begin{array}{l}\geq 1 \text { RNA- result w/in } \\
6 \text { months and } \geq 1 \\
\text { RNA- result for } \\
\text { additional } 6 \text { months }\end{array}$ & Moderate & 71 & 31 & 43.7 & 32.1 & - & 55.2 \\
\hline Shah (2012) [58] & $2004-2007$ & United States & Convenience sampling & $\begin{array}{l}\text { Community-based } \\
\text { setting }\end{array}$ & 1 RNA- result & Moderate & 272 & 43 & 15.8 & 11.5 & - & 20.1 \\
\hline Thomas (2000) [59] & 1988-1998 & United States & Convenience sampling & $\begin{array}{l}\text { Community-based } \\
\text { organization }\end{array}$ & $\begin{array}{l}2 \text { consecutive RNA- } \\
\text { results separated by } \\
\text { at least } 5 \text { months }\end{array}$ & High & 919 & 90 & 9.8 & 7.9 & - & 11.7 \\
\hline $\begin{array}{l}\text { van den Berg } \\
\text { (2011) [60] }\end{array}$ & $1985-2005$ & The Netherlands & Convenience sampling & $\begin{array}{l}\text { Clinical and drug } \\
\text { treatment settings }\end{array}$ & $\begin{array}{l}2 \text { consecutive RNA- } \\
\text { results separated by } \\
\text { at least } 4 \text { months }\end{array}$ & Moderate & 106 & 35 & 33.0 & 24.1 & - & 42.0 \\
\hline Wang (2007) [61] & $2003-2005$ & United States & Unspecified sampling & $\begin{array}{l}\text { Clinical and } \\
\text { research setting }\end{array}$ & $\begin{array}{l}2 \text { consecutive RNA- } \\
\text { results }\end{array}$ & High & 44 & 8 & 18.2 & 6.8 & - & 29.6 \\
\hline
\end{tabular}

Fixed-effect meta-analysis estimate of the prevalence of spontaneous viral clearance (28 studies): $15.1 \%(95 \% \mathrm{Cl} 14.2,16.0)$

Random-effects meta-analysis estimate of the prevalence of spontaneous viral clearance ( 28 studies): $24.3 \%$ (95 \% Cl 19.5, 29.1)

Heterogeneity: $Q=638.51, p<0.001: I^{2}=95.8 \%$ 


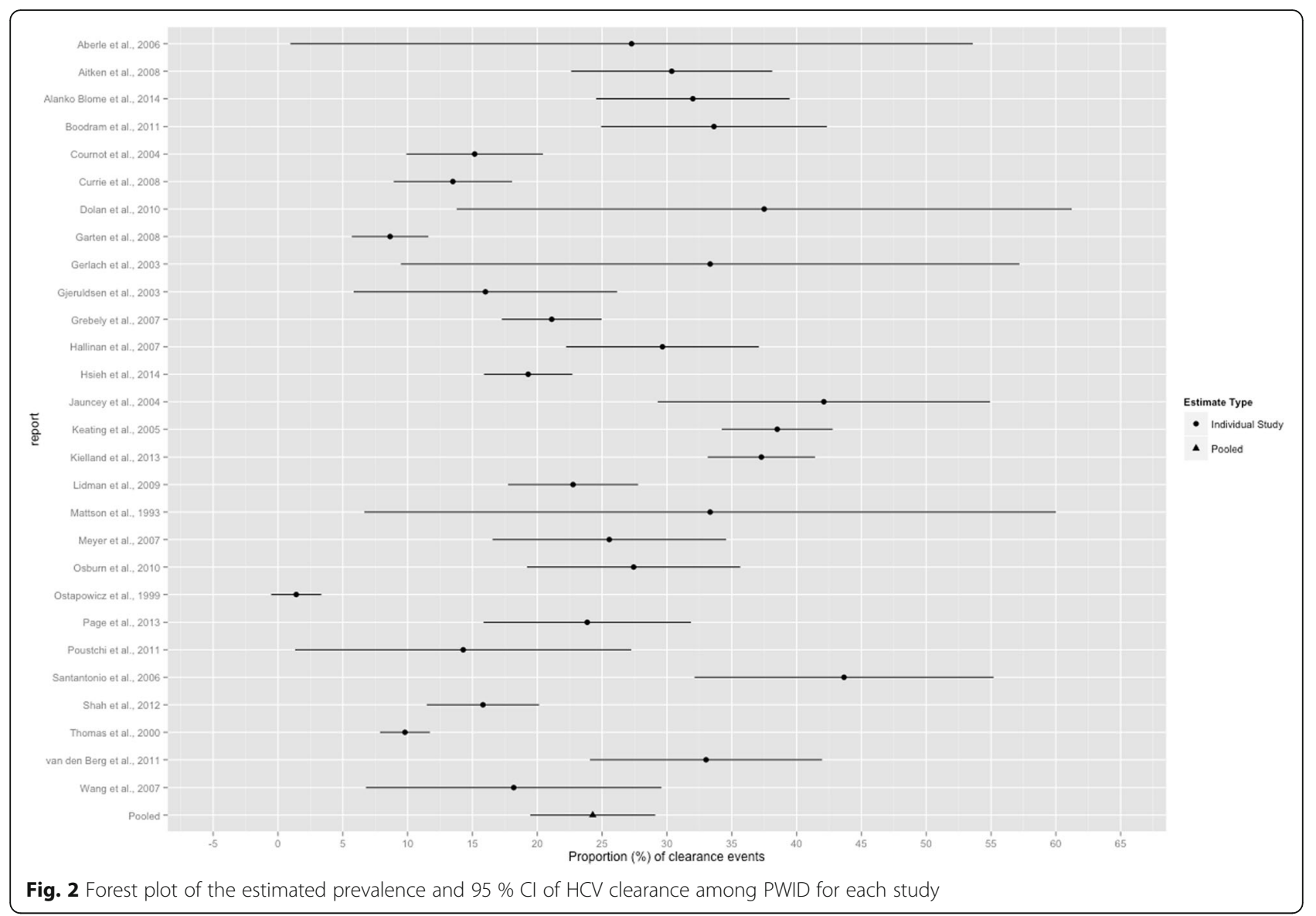

participants experienced spontaneous viral clearance. The random-effects meta-analysis estimate of the prevalence of spontaneous viral clearance was 15.4\% (95\% CI 11.5, 19.3; $Q=13.29, p=0.102 ; I^{2}=39.8 \%$ ). The forest plot in Fig. 4 provides the estimates from the contributing reports. Subgroup estimates based on quality rating also were obtained. As shown in Table 3, among high-, moderate-, and low-quality reports, prevalence of spontaneous viral clearance was 19.2, 15.8, and $11.3 \%$, respectively.

\section{Meta-regression}

To examine the effect of report and participant characteristics on the prevalence of spontaneous viral clearance, we conducted random-effects meta-regression. Because covariates hypothesized to contribute to spontaneous viral clearance were not consistently collected or reported across reports, our meta-regression was limited to a small set of factors. Both univariate and multivariate meta-regression were performed.

\section{PWID}

Only two variables were significant in univariate analysis: male sex and age $(p<0.05)$. Spontaneous viral clearance was lower in both males and older individuals. We examined the relationship among pairs of variables (specifically, male sex, HIV-positivity, and age) through contingency tables. Fisher's exact tests revealed no significant associations between factor dyads (results not shown; see Additional file 2). Of particular interest to our study was the impact of HIV. In our preferred multivariate model, presented in Table 4, male sex $(p<0.021)$ and HIV positivity $(p<0.036)$ were significant predictors.

\section{$H I V+M S M$}

Neither univariate nor multivariate analysis provided any evidence of an effect on spontaneous viral clearance of any of the variables (i.e., age, proportion on highly active antiretroviral therapy, recruitment site, and quality rating) evaluated.

\section{Discussion}

In this systematic review and meta-analysis, we estimated that the prevalence of spontaneous viral clearance is $24.4 \%$ in PWID and $15.4 \%$ in HIV+ MSM. Although the estimates for PWID and HIV+ MSM were not directly compared here, the difference may be related to 


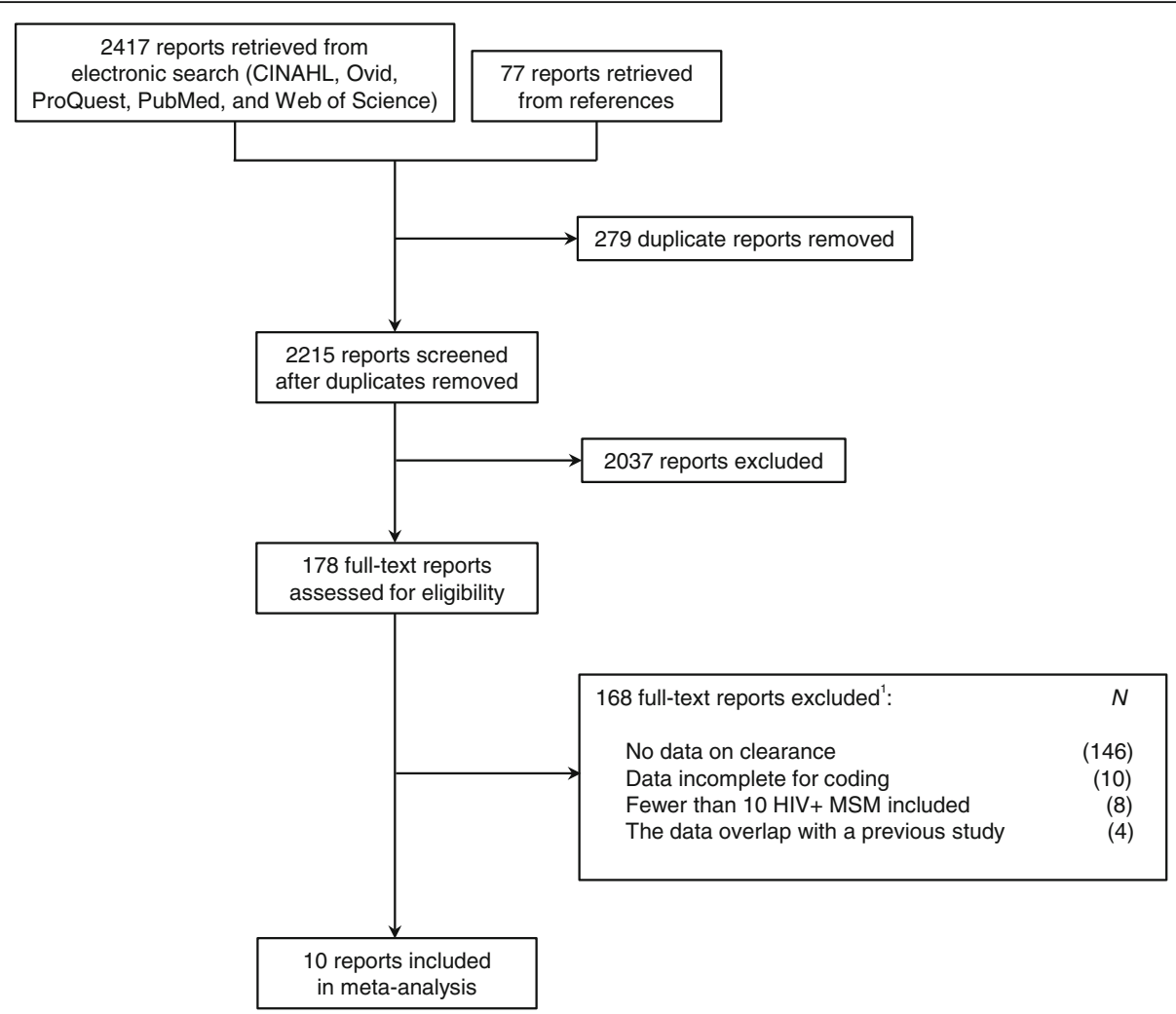

Fig. 3 Flow diagram of the literature search and eligibility assessment for HIV+ MSM. ${ }^{1}$ Reasons for exclusion are not mutually exclusive. A report may have been ineligible due to multiple reasons. Here, only one reason for exclusion is provided

the impact of HIV co-infection on the natural history of $\mathrm{HCV}$. The rates of spontaneous viral clearance were similar in HIV+ MSM (15.4 \%) and PWID with HIV infection at the time that $\mathrm{HCV}$ clearance was evaluated (16.1\%). Our estimate of $24.4 \%$ among PWID was very closely similar to the estimate from a pooled analysis of clearance among 632 participants in multiple studies (25\%) who were observed following acute infection [29].

Among HIV-positive PWID, lower clearance cannot reliably be attributed to the effect of HIV infection on viral kinetics because the temporal relation between HIV and $\mathrm{HCV}$ infections in these individuals is unclear. Moreover, estimates of spontaneous viral clearance from most studies do not necessarily represent true rates but rather the prevalence of cleared infection. Evidence of clearance at any given time in an individual is the cumulative result of behaviors that led to infection events, including multiple re-infections, and the host and viral characteristics that govern response to acute HCV infection. Although re-infection post-SVR is higher among HIV + MSM than among PWID, it cannot be concluded that the rates of $\mathrm{HCV}$ re-infection in treated and untreated HIV + MSM are higher than among treated and untreated PWID because studies of re-infection in treated PWID have in many cases excluded active injectors $[14,30]$. There is no research comparing the frequency of $\mathrm{HCV}$ transmission behavior between these groups, and thus, there is insufficient evidence to attribute differences in clearance to differences in behavioral risk.

Our finding that female gender was associated with higher proportions of spontaneous viral clearance events is consistent with published literature demonstrating that females are more likely to clear $\mathrm{HCV}$ than their male counterparts in a variety of settings and other patient groups [31, 32].

Evaluation of the report-level spontaneous viral clearance data for each of the populations indicates that the meta-analysis estimates were affected by notable degrees of heterogeneity. Among PWID, both male sex and age were associated with lower proportions of spontaneous viral clearance events. In examining spontaneous viral clearance estimates in HIV+ MSM, the results did not suggest the effect of any of the factors considered. Given the null findings in univariate meta-regression on quality rating $(p=0.163)$ and study design $(p=0.182)$, and noting the low volume of reports for which we extracted data on participant characteristics, heterogeneity was most likely due to unmeasured clinical, patient-level characteristics (e.g., ethnicity, genotype, other viral 
Table 2 Studies investigating spontaneous viral clearance of HCV among HIV+ MSM

\begin{tabular}{|c|c|c|c|c|c|c|c|c|c|c|c|c|}
\hline \multirow[t]{2}{*}{ First author (pub. yr.) } & \multirow[t]{2}{*}{ Study period } & \multirow[t]{2}{*}{ Location } & \multirow[b]{2}{*}{ Recruitment method } & \multirow[b]{2}{*}{ Recruitment site } & \multirow[b]{2}{*}{ Definition of HCV clearance } & \multirow[b]{2}{*}{ Quality rating } & \multicolumn{2}{|l|}{$N$} & \multirow[b]{2}{*}{$\begin{array}{l}\text { Proportion of } \\
\text { clearance events }\end{array}$} & \multirow{2}{*}{\multicolumn{2}{|c|}{$95 \% \mathrm{Cl}$}} & \\
\hline & & & & & & & Participants & Clearers & & & & \\
\hline Bottieau (2010) [62] & $2001-2009$ & Belgium & $\begin{array}{l}\text { Consecutive } \\
\text { sampling }\end{array}$ & Clinical setting & $\begin{array}{l}\geq 1 \text { RNA- within } \\
6 \text { months }\end{array}$ & Moderate & 65 & 7 & 10.8 & 3.2 & & 18.3 \\
\hline Dietz (2012) [63] & Not reported & Germany & Not reported & Not reported & Methods not reported & Low & 47 & 4 & 8.5 & 0.5 & & 16.5 \\
\hline Fierer(2014) [64] & Not reported & United States & Not reported & Not reported & $\begin{array}{l}\geq 1 \text { RNA- within } \\
3 \text { months }\end{array}$ & Moderate & 41 & 5 & 12.2 & 2.2 & 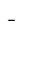 & 22.2 \\
\hline Fletcher (2003) [65] & 2002-2003 & United Kingdom & Not reported & Clinical setting & $\geq 1$ RNA-result & Moderate & 16 & 6 & 37.5 & 13.8 & & 61.2 \\
\hline Gilleece (2005) [66] & 1997-2003 & United Kingdom & Not reported & Clinical setting & $\begin{array}{l}>1 \text { RNA- result within } \\
3 \text { months }\end{array}$ & Moderate & 50 & 12 & 24.0 & 12.2 & & 35.8 \\
\hline Grebely (2014) [29] & 1985-2010 & Multiple locations & Not reported & $\begin{array}{l}\text { Clinical, community- } \\
\text { based, and } \\
\text { correctional settings }\end{array}$ & $\begin{array}{l}2 \text { consecutive RNA- } \\
\text { results separated by at } \\
\text { least } 1 \text { month }\end{array}$ & Moderate & 11 & 0 & - & - & & \\
\hline Martin (2013) [67] & 2004-2014 & United Kingdom & $\begin{array}{l}\text { Consecutive } \\
\text { sampling }\end{array}$ & Clinical setting & $\begin{array}{l}2 \text { RNA- results after } \\
6 \text { months }\end{array}$ & High & 145 & 31 & 21.4 & 14.7 & & 28.1 \\
\hline Piroth (2010) [68] & 2008-2009 & France & $\begin{array}{l}\text { Consecutive } \\
\text { sampling }\end{array}$ & Clinical setting & $\geq 1$ RNA- & High & 53 & 8 & 15.1 & 5.5 & & 24.7 \\
\hline Sasadeusz (2011) [69] & $2003-2007$ & Not reported & $\begin{array}{l}\text { Consecutive } \\
\text { sampling }\end{array}$ & Clinical setting & $\begin{array}{l}2 \text { consecutive RNA- } \\
\text { results separated by at } \\
\text { least } 3 \text { months }\end{array}$ & Low & 61 & 9 & 14.8 & 5.9 & & 23.7 \\
\hline Thomson (2011) [70] & $2005-2009$ & United Kingdom & Not reported & Clinical setting & $\begin{array}{l}2 \text { consecutive RNA- } \\
\text { results separated by at } \\
\text { least } 3 \text { months }\end{array}$ & Moderate & 99 & 14 & 14.1 & 7.3 & & 21.0 \\
\hline
\end{tabular}

Fixed-effect meta-analysis estimate of the prevalence of spontaneous viral clearance (9 studies): $15.2 \%$ (95\% Cl 12.3, 18.1)

Random-effects meta-analysis estimate of the prevalence of spontaneous viral clearance ( 9 studies): $15.4 \%$ (95 \% Cl 11.5, 19.3)

Heterogeneity: $Q=13.29, p=0.102 ; l^{2}=39.8 \%$ 


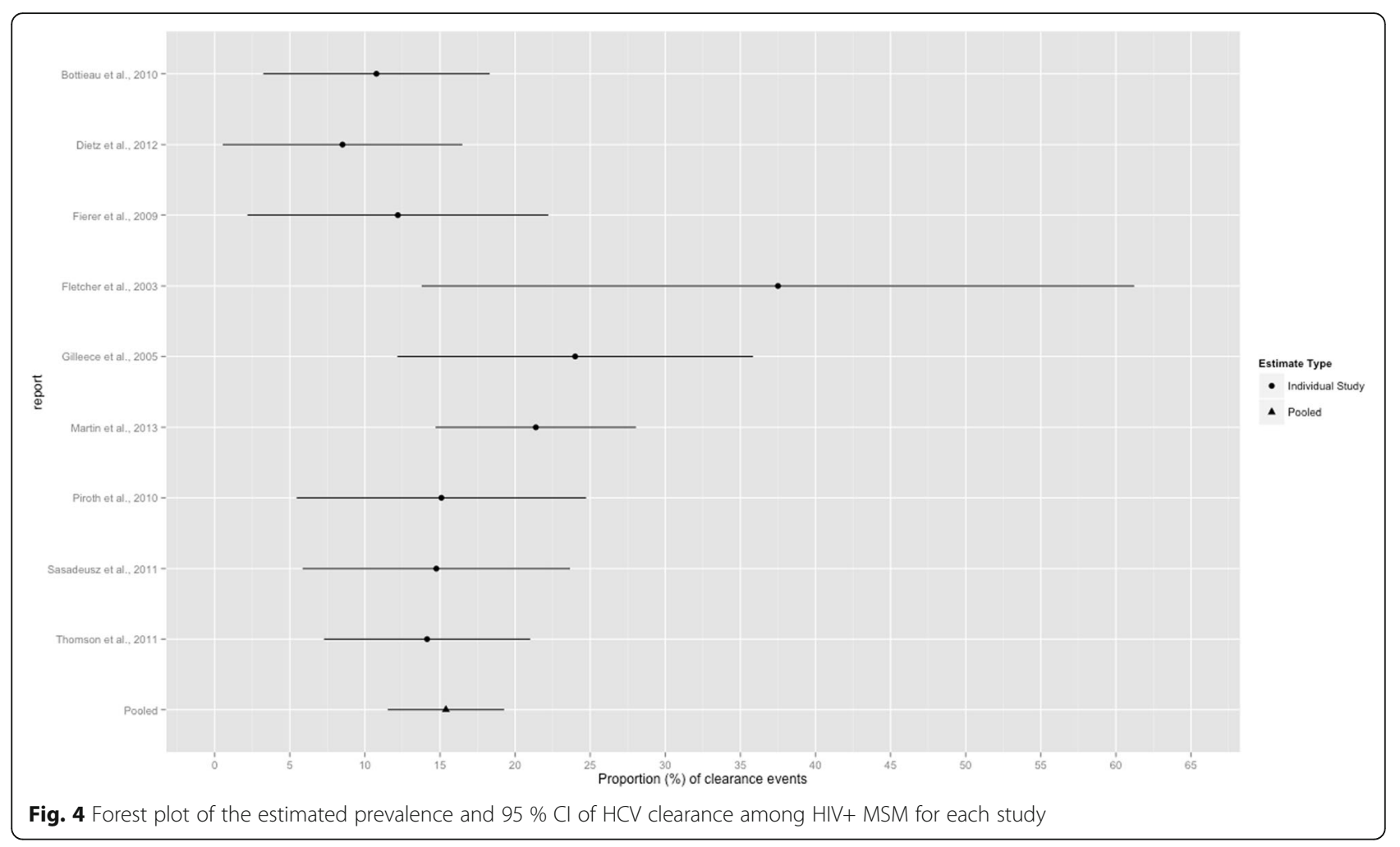

infections) rather than methodological characteristics. However, our analysis of sources of heterogeneity was limited by the dearth of information about time to event, viral factors, and other participant attributes.

\section{Limitations}

There are limitations to the meta-analysis that should be considered. One critical point is that the results of this review suggest, but do not explain, the mechanisms that lead to spontaneous viral clearance. Another important consideration is that the study methods and data provided by some of the contributing reports to this review presented challenges to the characterization of clearance in PWID and HIV+ MSM. We discuss here the main issues related to the contributing reports.

First, the samples of PWID examined in the included reports were not composed solely of individuals with a single $\mathrm{HCV}$ infection event, and, therefore, the estimates likely represented clearance in relation to cumulative

Table 3 Prevalence of spontaneous viral clearance among PWID and HIV+ MSM stratified by quality rating

\begin{tabular}{lllllll}
\hline & \multicolumn{2}{l}{ PWID } & & & \multicolumn{2}{l}{ HIV+ MSM } \\
\cline { 2 - 3 } Quality rating & Estimate & No. of reports & & Estimate & No. of reports \\
\hline High & 27.6 & 9 & 19.2 & 2 \\
Moderate & 24.1 & 16 & 15.8 & 5 \\
Low & 15.4 & 3 & 11.3 & 2 \\
\hline
\end{tabular}

HCV exposures via ongoing injection risk behavior [33]. Indeed, among PWID, rates of re-infection following spontaneous viral clearance are as high as 47 cases per 100 person-years [2]. Additionally, low rates of clearance observed among HIV+ PWID may represent frequent risk behavior that led to HIV infection and HCV re-infection. The high heterogeneity in the clearance estimates for both PWID and HIV+ MSM may in fact represent variability in the number of $\mathrm{HCV}$ infection events, in addition to genetic and other factors.

Second, the cross-sectional study design of most of the reports also limits interpreting the estimates vis-à-vis the underlying process.

Third, and related to the previous point, the definition of spontaneous viral clearance also was not uniform across studies. In particular, the criteria for spontaneous viral clearance events were notably different between cross-sectional and longitudinal reports.

Table 4 Random-effects meta-regression results for spontaneous viral clearance among PWID

\begin{tabular}{lllllll}
\hline Factor & $\beta$ & SE & $p$ & $95 \% \mathrm{Cl}$ & \\
\hline HIV-positive (\%) & -0.253 & 0.105 & 0.036 & -0.487 & -0.020 \\
Males (\%) & -0.414 & 0.151 & 0.021 & -0.750 & -0.078 \\
Constant & 59.638 & 11.252 & 0.000 & 34.567 & - & 84.710 \\
No. of reports & 13 & & & & & \\
\hline
\end{tabular}




\section{Conclusion}

This systematic review and meta-analysis suggests that the prevalence of spontaneous viral clearance is higher among PWID compared to HIV+ MSM. Our findings also showed that, among PWID, male sex and HIV co-infection are negatively correlated with clearance. The data we presented are useful for modeling future morbidity, mortality, and costs related to HCV infection. Improved research methodology and examination of individual characteristics in future studies would help to determine the natural course of HCV among the high-risk populations of PWID and HIV+ MSM, and appropriate allocation of resources for HCV treatment.

\section{Additional files}

Additional file 1: Search strategies by risk group. Provides the search strings used to locate literature across the electronic databases for both the PWID and HIV+ MSM risk groups. (PDF $6 \mathrm{~kb}$ )

Additional file 2: Fisher's exact tests for variables associated with spontaneous viral clearance among PWID. Provides the results of Fisher's exact tests for variables associated with spontaneous viral clearance among the PWID samples. (PDF $7 \mathrm{~kb}$ )

\section{Acknowledgements}

None.

\section{Funding}

This study is supported by the National Institutes of Health, grant numbers 1R01DA034637 and P30 DA011041.

\section{Availability of data and materials}

The data from the contributing studies will not be shared as the data already are available in the individual reports [see reference nos. [29, 34-70]. The literature search strategies and the results of Fisher's exact tests for PWID variables are available in the supplementary files.

\section{Authors' contributions}

$\mathrm{HH}$ designed the study, and $\mathrm{HH}$ and $\mathrm{AJ}$ developed study protocols. All authors contributed to the search and selection of the literature, collection and extraction of the data, and the writing of the protocols and manuscript. DS and MF conducted data analysis, and all authors were involved in the interpretation of the results. All authors read and approved the final manuscript.

\section{Authors' information}

None.

\section{Competing interests}

The authors declare that they have no competing interests.

\section{Consent for publication}

Not applicable.

Ethics approval and consent to participate Not applicable.

\section{Author details}

${ }^{1}$ Rory Meyers College of Nursing, New York University, New York, NY 10010, USA. ${ }^{2}$ Center for Drug Use and HIV Research, New York University, New York, NY 10010, USA.

Received: 9 February 2016 Accepted: 25 August 2016

Published online: 05 September 2016

\section{References}

1. Mohd Hanafiah K, Groeger J, Flaxman AD, Wiersma ST. Global epidemiology of hepatitis C virus infection: New estimates of age-specific antibody to HCV seroprevalence. Hepatology. 2013:57:1333-42.

2. Grebely J, Prins M, Hellard M, Cox AL, Osburn WO, Lauer G, et al. Hepatitis $C$ virus clearance, reinfection, and persistence, with insights from studies of injecting drug users: towards a vaccine. Lancet Infect Dis. 2012;12:408-14.

3. Hadigan C, Kottilil S. Hepatitis C virus infection and coinfection with human immunodeficiency virus: challenges and advancements in management. JAMA. 2011;306:294-301.

4. Hajarizadeh B, Grebely J, Dore GJ. Epidemiology and natural history of HCV infection. Nat Rev Gastroenterol Hepatol. 2013;10:553-62.

5. Hagan H, Pouget ER, Williams IT, Garfein RL, Strathdee SA, Hudson SM, et al. Attribution of hepatitis $C$ virus seroconversion risk in young injection drug users in 5 US cities. J Infect Dis. 2010;201:378-85

6. Nelson PK, Mathers BM, Cowie B, Hagan H, Des Jarlais D, Horyniak D, et al. Global epidemiology of hepatitis B and hepatitis $C$ in people who inject drugs: results of systematic reviews. Lancet. 2011:378:571-83.

7. Jordan AE, Des Jarlais DC, Arasteh K, McKnight C, Nash D, Perlman DC. Incidence and prevalence of hepatitis $C$ virus infection among persons who inject drugs in New York City: 2006-2013. Drug Alcohol Depend. 2015;152:194-200.

8. Hagan H, Des Jarlais DC. HIV and HCV infection among injecting drug users. Mt Sinai J Med. 2000;67:423-8.

9. Hernando V, Perez-Cachafeiro S, Lewden C, Gonzalez J, Segura F, Oteo JA, et al. All-cause and liver-related mortality in HIV positive subjects compared to the general population: differences by HCV co-infection. J Hepatol. 2012;57:743-51

10. van der Helm J, Geskus R, Sabin C, Meyer L, Del Amo J, Chêne G, et al. Effect of HCV infection on cause-specific mortality after HIV seroconversion, before and after 1997. Gastroenterology. 2013;144:751-60.

11. Sulkowski MS. Current management of hepatitis $C$ virus infection in patients with HIV co-infection. J Infect Dis. 2013;207:S26-32.

12. Alter MJ. HCV routes of transmission: what goes around comes around. Semin Liver Dis. 2011:31:340-6.

13. Thomas DL. Global control of hepatitis C: where challenge meets opportunity. Nat Med. 2013;19:850-8.

14. Hagan $H$, Jordan AE, Neurer J, Cleland CM. Incidence of sexually transmitted hepatitis C virus infection in HIV-positive MSM: a systematic review and meta-analysis. AIDS. 2015;29:2335-45

15. Jordan AE, Perlman DC, Neurer J, Smith DJ, Des Jarlais DC, Hagan H. Prevalence of hepatitis $C$ virus infection among HIV+ men who have sex with men: A systematic review and meta-analysis. Int J STD AIDS. 2016; In press.

16. Hagan H, Neurer J, Jordan AE, Des Jarlais DC, Wu J, Dombrowski K, et al. Hepatitis $C$ virus infection among HIV-positive men who have sex with men: protocol for a systematic review and meta-analysis. Syst Rev. 2014:3:31-7

17. Jordan $A E$, Jarlais DD, Hagan $H$. Prescription opioid misuse and its relation to injection drug use and hepatitis $C$ virus infection: protocol for a systematic review and meta-analysis. Syst Rev. 2014;3:95-9.

18. Combellick J, Smith DJ, Jordan AE, Hagan $\mathrm{H}$. Hepatitis $\mathrm{C}$ virus disease progression in people who inject drugs: protocol for a systematic review and meta-analysis. JMIR Res Protoc. 2015;4:e68.

19. Smith DJ, Combellick J, Jordan AE, Hagan H. Hepatitis C virus (HCV) disease progression in people who inject drugs (PWID): a systematic review and meta-analysis. Int J Drug Policy. 2015;26:911-21.

20. Moher D, Liberati A, Tetzlaff J, Altman D. Preferred reporting items for systematic reviews and meta-analyses: the PRISMA statement. PLoS Med. 2009;6:e1000097.

21. Te HS, Jensen DM. Epidemiology of hepatitis B and C viruses: a global overview. Clin Liver Dis. 2010;14:1-21.

22. Franco E, Bagnato B, Marino MG, Meleleo C, Serino L, Zaratti L. Hepatitis B: epidemiology and prevention in developing countries. World J Hepatol. 2012:4:74-80.

23. Johansson KA, Robberstad B, Norheim OF. Further benefits by early start of HIV treatment in low income countries: survival estimates of early versus deferred antiretroviral therapy. AIDS Res Ther. 2010;7:3

24. European AIDS Treatment Network (NEAT) Acute Hepatitis C Infection Consensus Panel. Acute hepatitis C in HIV-infected individuals: 
recommendations from the European AIDS treatment network (NEAT) consensus conference. AIDS. 2011;25:399-409.

25. Hayden JA, Côté P, Bombardier C. Evaluation of the quality of prognosis studies in systematic reviews. Ann Intern Med. 2006;144:427-37.

26. Hayden J, van der Windt D, Cartwright J, Côté P, Bombardier C. Assessing bias in studies of prognostic factors. Ann Intern Med. 2013;158:280-6.

27. Higgins J, Thompson S, Deeks J, Altman D. Measuring inconsistency in meta-analyses. BMJ. 2003;327:557-60.

28. StataCorp. Stata statistical software: release 13. College Station: StataCorp LP; 2013

29. Grebely J, Page K, Sacks-Davis R, van der Loeff MS, Rice TM, Bruneau J, et al. The effects of female sex, viral genotype, and IL28B genotype on spontaneous clearance of acute hepatitis C virus infection. Hepatology. 2014;59:109-20.

30. Aspinall EJ, Corson S, Doyle JS, Grebely J, Hutchinson SJ, Dore GJ, et al. Treatment of hepatitis $C$ virus infection among people who are actively injecting drugs: a systematic review and meta-analysis. Clin Infect Dis. 2013;15:S80-9.

31. Bakr I, Rekacewicz C, Hosseiny ME, Ismail S, El Daly M, El-Kafrawy S, et al. Higher clearance of hepatitis $C$ virus infection in females compared with males. Gut. 2006;55:1183-7.

32. Micallef JM, Kaldor JM, Dore GJ. Spontaneous viral clearance following acute hepatitis $C$ infection: a systematic review of longitudinal studies. J Viral Hepat. 2006;13:34-41.

33. Matthews GV, Grebely J, Dore GJ. The role of re-infection in determining rates of spontaneous clearance after hepatitis C exposure. J Hepatol. 2008:49:305-7.

34. Aberle JH, Formann E, Steindl-Munda P, Weseslindtner L, Gurguta C, Perstinger $G$, et al. Prospective study of viral clearance and CD4(+) T-cell response in acute hepatitis $C$ primary infection and reinfection. J Clin Virol. 2006;36:24-31.

35. Aitken CK, Lewis J, Tracy SL, Spelman T, Bowden DS, Bharadwaj M, et al. High incidence of hepatitis $C$ virus reinfection in a cohort of injecting drug users. Hepatology. 2008:48:1746-52.

36. Alanko Blomé $M$, Björkman $P$, Molnegren $V$, Höglund $P$, Widell $A$. Hepatitis $C$ viremia patterns in incident hepatitis $C$ infection and one year later in 150 prospectively tested persons who inject drugs. PLoS One. 2014;9:e97022.

37. Boodram B, Hershow RC, Cotler SJ, Ouellet LJ. Chronic hepatitis C virus infection and increases in viral load in a prospective cohort of young, HIV-uninfected injection drug users. Drug Alcohol Depend. 2011;119:166-71.

38. Cournot M, Glibert A, Castel F, Druart F, Imani K, Lauwers-Cances V, et al. Management of hepatitis $C$ in active drugs users: experience of an addiction care hepatology unit. Gastroenterol Clin Biol. 2004;28:533-9.

39. Currie SL, Ryan JC, Tracy D, Wright TL, George S, McQuaid R, et al. A prospective study to examine persistent HCV reinfection in injection drug users who have previously cleared the virus. Drug Alcohol Depend. 2008;93:148-54.

40. Dolan K, Teutsch S, Scheuer N, Levy M, Rawlinson W, Kaldor J, et al. Incidence and risk for acute hepatitis $C$ infection during imprisonment in Australia. Eur J Epidemiol. 2010;25:143-8.

41. Garten RJ, Lai SH, Zhang JB, Liu W, Chen J, Yu XF. Factors influencing a low rate of hepatitis $C$ viral RNA clearance in heroin users from Southern China. World J Gastroenterol. 2008;14:1878-84.

42. Gerlach JT, Diepolder HM, Zachoval R, Gruener NH, Jung MC, Ulsenheimer A, et al. Acute hepatitis $C$ : high rate of both spontaneous and treatmentinduced viral clearance. Gastroenterology. 2003;125:80-8.

43. Gjeruldsen SR, Myrvang B, Opjordsmoen S. A 25-year follow-up study of drug addicts hospitalised for acute hepatitis: present and past morbidity. Eur Addict Res. 2003:9:80-6.

44. Grebely J, Raffa JD, Lai C, Krajden M, Conway B, Tyndall MW. Factors associated with spontaneous clearance of hepatitis $C$ virus among illicit drug users. Can J Gastroenterol. 2007;21:447-51.

45. Hallinan R, Byrne A, Agho K, Dore GJ. Referral for chronic hepatitis $C$ treatment from a drug dependency treatment setting. Drug Alcohol Depend. 2007;88:49-53.

46. Hsieh MH, Tsai JJ, Hsieh MY, Huang CF, Yeh ML, Yang JF, et al. Hepatitis $C$ virus infection among injection drug users with and without human immunodeficiency virus co-infection. PLoS One. 2014;9:e94791.
47. Jauncey M, Micallef JM, Gilmour S, Amin J, White PA, Rawlinson W, et al Clearance of hepatitis $C$ virus after newly acquired infection in injection drug users. J Infect Dis. 2004;190:1270-4.

48. Keating S, Coughlan S, Connell J, Sweeney B, Keenan E. Hepatitis C viral clearance in an intravenous drug-using cohort in the Dublin area. Ir J Med Sci. 2005;174:37-41.

49. Kielland KB, Skaug K, Amundsen EJ, Dalgard O. All-cause and liver-related mortality in hepatitis $C$ infected drug users followed for 33 years: a controlled study. J Hepatol. 2013;58:31-7.

50. Lidman C, Norden L, Kåberg M, Käll K, Franck J, Aleman S, et al. Hepatitis C infection among injection drug users in Stockholm Sweden: prevalence and gender. Scand J Infect Dis. 2009;41:679-84.

51. Mattsson L, Sönnerborg A, Weiland O. Outcome of acute symptomatic non-A, non-B hepatitis: a 13-year follow-up study of hepatitis $C$ virus markers. Liver. 1993:13:274-8.

52. Meyer MF, Wedemeyer H, Monazahian M, Dreesman J, Manns MP, Lehmann M. Prevalence of hepatitis $C$ in a German prison for young men in relation to country of birth. Epidemiol Infect. 2007;135:274-80.

53. Osburn WO, Fisher BE, Dowd KA, Urban G, Liu L, Ray SC, et al. Spontaneous control of primary hepatitis $C$ virus infection and immunity against persistent reinfection. Gastroenterology. 2010;138:315-24.

54. Ostapowicz G, Bell SJ, Desmond PV. Severity of liver disease in hepatitis C infection contracted through injecting drug use. Aust N Z J Med. 1999;29:776-81.

55. Page K, Osburn W, Evans J, Hahn JA, Lum P, Asher A, et al. Frequent longitudinal sampling of hepatitis $C$ virus infection in injection drug users reveals intermittently detectable viremia and reinfection. Clin Infect Dis. 2013:56:405-13.

56. Poustchi H, Esmaili S, Mohamadkhani A, Nikmahzar A, Pourshams A, Sepanlou SG, et al. The impact of illicit drug use on spontaneous hepatitis C clearance: experience from a large cohort population study. PLoS One. 2011;6:e23830

57. Santantonio T, Medda E, Ferrari C, Fabris P, Cariti G, Massari M, et al. Risk factors and outcome among a large patient cohort with communityacquired acute hepatitis C in Italy. Clin Infect Dis. 2006;43:1154-9.

58. Shah DP, Grimes CZ, Brown E, Hwang LY. Demographics, socio-behavioral factors, and drug use patterns: what matters in spontaneous HCV clearance? J Med Virol. 2012;84:235-41.

59. Thomas DL, Astemborski J, Rai RM, Anania FA, Schaeffer M, Galai N, et al. The natural history of hepatitis $C$ virus infection: host, viral, and environmental factors. JAMA. 2000;284:450-6.

60. van den Berg CH, Grady BP, Schinkel J, van de Laar T, Molenkamp R, van Houdt R, et al. Female sex and IL28B, a synergism for spontaneous viral clearance in hepatitis $\mathrm{C}$ virus ( $\mathrm{HCV}$ ) seroconverters from a community-based cohort. PLoS One. 2011;6:e27555.

61. Wang CC, Krantz E, Klarquist J, Krows M, McBride L, Scott EP, et al. Acute hepatitis $C$ in a contemporary US cohort: modes of acquisition and factors influencing viral clearance. J Infect Dis. 2007;196:1474-82.

62. Bottieau E, Apers L, Van Esbroeck M, Vandenbruaene M, Florence E. Hepatitis C virus infection in HIV-infected men who have sex with men: sustained rising incidence in Antwerp, Belgium, 2001-2009. Euro Surveill. 2010;15:19673.

63. Dietz J, Lutz T, Knechi G, Gute P, Carlebach A, Grammatikos G, et al. Investigation of viral and host factors associated with outcome of acute hepatitis $C$ in a cohort of patients with HIV coinfection. Antivir Ther. 2012;17:A97.

64. Fierer DS, Dieterich DT, Mullen MP, Branch AD, Uriel AJ, Carriero DC, et al. Telaprevir in the treatment of acute hepatitis $C$ virus infection in HIVinfected men. Clin Infect Dis. 2014;58:873-9.

65. Fletcher S. Sexual transmission of hepatitis $C$ and early intervention. J Assoc Nurses AIDS Care. 2003;14:87s-94s.

66. Gilleece $Y C$, Browne RE, Asboe D, Atkins M, Mandalia S, Bower M, et al. Transmission of hepatitis C virus among HIV-positive homosexual men and response to a 24-week course of pegylated interferon and ribavirin. J Acquir Immune Defic Syndr. 2005;40:41-6.

67. Martin TC, Martin NK, Hickman M, Vickerman P, Page EE, Everett R, et al. Hepatitis $C$ virus reinfection incidence and treatment outcome among HIV-positive MSM. AIDS. 2013;27:2551-7.

68. Piroth L, Larsen C, Binquet C, Alric L, Auperin I, Chaix ML, et al. Treatment of acute hepatitis $C$ in human immunodeficiency virus-infected patients: the HEPAIG study. Hepatology. 2010;52:1915-21. 
69. Sasadeusz J, Rodger A, Fernandez T, Bhagani S. High rates of sexually transmitted HCV re-infection in HIV positive men who have sex with men: prevention is the key [poster 1179]. J Hepatol. 2011;54:5466.

70. Thomson EC, Fleming VM, Main J, Klenerman P, Weber J, Eliahoo J, et al. Predicting spontaneous clearance of acute hepatitis $C$ virus in a large cohort of HIV-1-infected men. Gut. 2011;60:837-45.

Submit your next manuscript to BioMed Central and we will help you at every step:

- We accept pre-submission inquiries

- Our selector tool helps you to find the most relevant journal

- We provide round the clock customer support

- Convenient online submission

- Thorough peer review

- Inclusion in PubMed and all major indexing services

- Maximum visibility for your research

Submit your manuscript at www.biomedcentral.com/submit 